\title{
Membrane Operations for Industrial Applications
}

\author{
Maria Giovanna Buonomenna ${ }^{1,{ }^{*},}$, Giovanni Golemme ${ }^{1,{ }^{*}}$ and Enrico Perrotta ${ }^{2}$ \\ ${ }^{1}$ Department of Chemical Engineering and Materials and \\ INSTM Consortium, University of Calabria, Rende (CS) \\ ${ }^{2}$ Department of Ecology, University of Calabria, Rende (CS) \\ Italy
}

\section{Introduction}

A resource-intensive industrial development, particularly in some Asian countries, characterized the last century. Its main causes can be ascribed to the significant elongation of life expectation, and to the overall increase in the standards characterizing the quality of life. The drawback of these positive aspects is the emergence of problems related to the industrial development: water stress, the environmental pollution, and the increase of $\mathrm{CO}_{2}$ emissions into the atmosphere.

The need to achieve a knowledge-intensive industrial development is nowadays well recognized. This will permit the transition from an industrial system based on quantity to one based on quality in the framework of a sustainable development.

Sustainable development is a development that meets the needs of the present without compromising the ability of future generations to meet their own needs (United Nations General Assembly, 1987). The "three pillars" of sustainability are the environmental, social and economic demands - (United Nations General Assembly, 1987), which are not mutually exclusive and can be mutually reinforced (Figure 1): both economy and society are constrained by environmental limits. Sustainability is the path of continuous improvement, wherein the products and services required by society are delivered with progressively less negative impacts upon the Earth. Figure 2 is a cartoon depicting the road to sustainability. To benchmark sustainability, the Sustainability Index (SI) accounts for key factors that are fundamental to the industrial process (Cobb et al, 2007)

- $\quad$ strategic commitment to sustainability

- safety performance

- environmental performance

- $\quad$ social responsibility

- product stewardship

- innovation

- value-chain management

${ }^{*}$ Corresponding Authors 


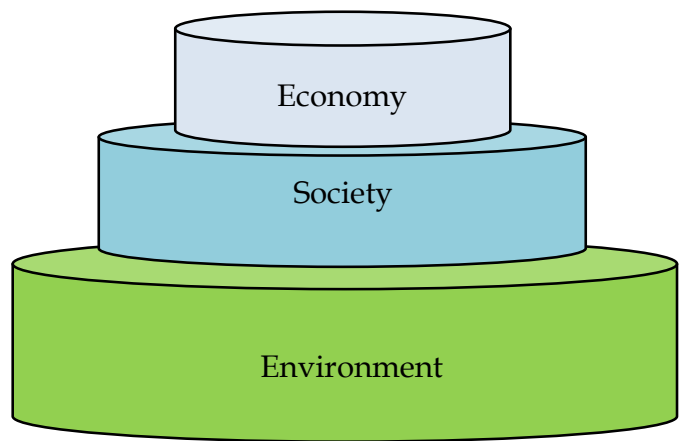

Fig. 1. Relationship between the three pillars of sustainability: environmental limits constrain both society and economy.
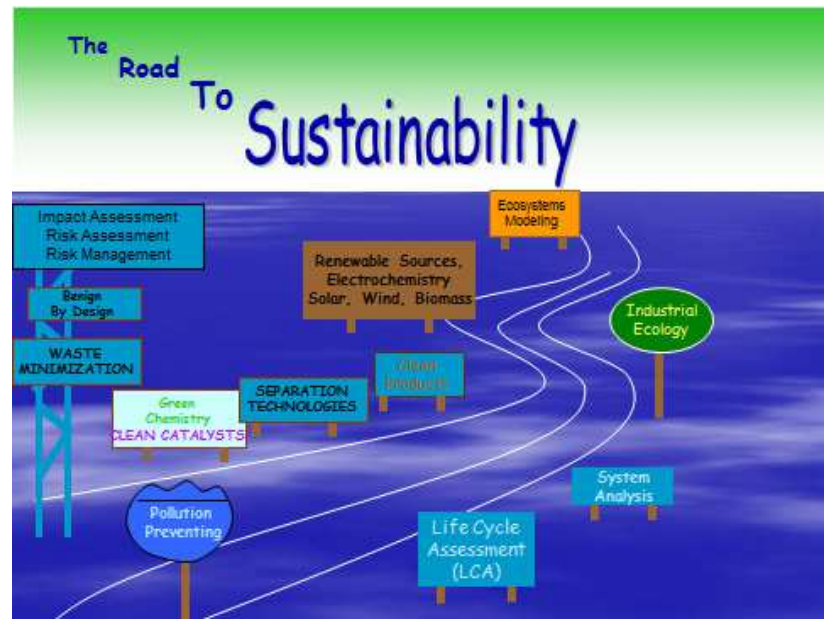

Fig. 2. Cartoon showing the features and the requirements of the road to sustainability

Chemical Engineering faces today the crucial challenge of sustainable growth to find solutions to the increasing demand for raw materials, energy and tailor-made products.

In this context, the rational integration and implementation of innovative technologies, able to increase process performance, save energy, reduce costs, and minimize the environment impact represent interesting answers.

Recently, the logic of process intensification has been suggested as the best process engineering answer to the situation. It consists of innovative equipment, design, and process development methods that are expected to bring substantial improvements in chemical and any other manufacturing and processing, such as decreasing production costs, equipment size, energy consumption, and waste generation, and improving remote control, information fluxes, and process flexibility (Charpentier, 2007).

Membrane operations are, in principle, the most attractive candidates to satisfy the process intensification concepts and requirements. 
Their intrinsic characteristics of efficiency and operational simplicity, high selectivity and permeability for the transport of specific components, compatibility between different membrane operations in integrated systems, low energetic requirement, good stability under operating conditions and environmental compatibility, easy control and scale-up, and large operational flexibility, represent an interesting answer for the rationalization of industrial productions (Drioli \& Romano, 2001).

The traditional membrane separation operations such as reverse osmosis (RO), microfiltration (MF), ultrafiltration (UF), and nanofiltration (NF), electrodialysis, pervaporation, etc. (Table 1), are largely used in many different applications.

\begin{tabular}{|c|c|c|c|c|}
\hline Driving Force & $\begin{array}{c}\text { Pressure } \\
\text { difference } \\
\qquad(\Delta \mathrm{P})\end{array}$ & $\begin{array}{l}\text { Concentration } \\
\text { difference } \\
(\Delta \mathrm{C})\end{array}$ & $\begin{array}{c}\text { Temperature } \\
\text { difference } \\
(\Delta \mathrm{T})\end{array}$ & $\begin{array}{l}\text { Electrical } \\
\text { potential } \\
\text { difference } \\
(\Delta \mathrm{f})\end{array}$ \\
\hline $\begin{array}{c}\text { Phenomenological } \\
\text { Equation }\end{array}$ & Darcy's law & Fick's law & Fourier's law & Ohm's law \\
\hline \multirow{4}{*}{$\begin{array}{l}\text { Membrane } \\
\text { Operations }\end{array}$} & $\begin{array}{l}\text { Microfiltration } \\
(\mathrm{MF})\end{array}$ & $\begin{array}{l}\text { Gas separation } \\
\text { (GS) }\end{array}$ & $\begin{array}{l}\text { Membrane } \\
\text { distillation } \\
(\mathrm{MD})\end{array}$ & $\begin{array}{l}\text { Electro-dialysis } \\
\text { (ED) }\end{array}$ \\
\hline & $\begin{array}{l}\text { Ultrafiltration } \\
\text { (UF) }\end{array}$ & $\begin{array}{l}\text { Pervaporation } \\
(\mathrm{PV})\end{array}$ & & $\begin{array}{l}\text { Electro-osmosis } \\
(\mathrm{EO})\end{array}$ \\
\hline & $\begin{array}{l}\text { Nanofiltration } \\
(\mathrm{NF})\end{array}$ & Dialysis (D) & & \\
\hline & $\begin{array}{l}\text { Reverse osmosis } \\
(\mathrm{RO})\end{array}$ & $\begin{array}{l}\text { Reverse osmosis } \\
(\mathrm{RO})\end{array}$ & & \\
\hline
\end{tabular}

Table 1. Classification of membrane processes according to their driving forces

Conventional membrane separation processes have at least two phase interfaces: feed fluidmembrane interface and product/permeate fluid-membrane interface on the two sides of the membrane. For example, commercialized membrane separation processes, such as $\mathrm{RO}$, NF, UF, MF, GS, and PV, have two such phase interfaces. Over the last couple of decades, new membranes and membrane-separation techniques have appeared wherein the interface between two bulk phases is allowing the development of a new (improved) membrane, the creation of a novel membrane separation technique, the enhancement of the separation in existing membrane-separation processes, or the enhancement of the separation as such. The impact of such new techniques on conventional equilibrium-based separation processes/techniques is striking. The nature of the phase interface in such techniques is often crucial.

These innovative membrane systems, the separation principle of which is the phase equilibrium and known as membrane contactors, have been studied, realised, and used in integrated membrane processes. In Table 2, a classification of the different types of membrane contactors is given. 


\begin{tabular}{lllllll}
\hline & $\begin{array}{l}\text { Membrane } \\
\text { distillation } \\
\text { (MD) }\end{array}$ & $\begin{array}{l}\text { Membrane } \\
\text { strippers/ } \\
\text { scrubbers }\end{array}$ & $\begin{array}{l}\text { Osmotic } \\
\text { distillation } \\
\text { (OD) }\end{array}$ & $\begin{array}{l}\text { Membrane } \\
\text { emulsifiers }\end{array}$ & $\begin{array}{l}\text { Membrane } \\
\text { crystallizers } \\
\text { (MCr) }\end{array}$ & $\begin{array}{l}\text { Phase } \\
\text { transfer } \\
\text { catalysis }\end{array}$ \\
\hline Phase 1 & LIQUID & GAS/LIQUID & LIQUID & LIQUID & LIQUID & LIQUID \\
Phase 2 & LIQUID & LIQUID & LIQUID & LIQUID & LIQUID & LIQUID \\
Driving & PARTIAL & CONCENTR. & PARTIAL & PRESSURE & PARTIAL & CONCENTR. \\
force & PRESSURE & GRADIENT & $\begin{array}{l}\text { PRESSURE } \\
\text { GRADIENT }\end{array}$ & $\begin{array}{l}\text { PRESSURE } \\
\text { GRADIENT }\end{array}$ & GRADADIENT \\
& GRADIENT & & GRADIENT & & GRADIENT \\
Limit to & TEMPERAT. & RESISTANCE & CONCENTR. RESISTANCE & TEMPERAT. & RESISTAN. \\
transport & POLARIZ. & IN MEMBR. & POLARIZ. & IN MEMBR. & CONCENTR. IN MEMBR. \\
& & Or LIQUID & & Or LIQUID & POLARIZ. & OR LIQUID \\
\hline
\end{tabular}

Table 2. Classification of membrane contactors

At present, redesigning important industrial production cycles by combining various membrane operations suitable for separation and conversion units, thus realizing highly integrated membrane processes, is an attractive opportunity because of the synergic effects that can be attained.

In various fields, membrane operations are already the dominant technology. Their utilizations as hybrid systems, in combination with other conventional techniques or integrated with different membrane operations, is considered the way forward rationale applications.

In this context, interesting examples are in seawater desalination ; in wastewater treatment and reuse ; and in gas separation.

\section{Seawater desalination}

Sea and brackish water desalination has been at the origin of the interest for membrane operations, and the research efforts on RO membranes have had an impact on all of the progress in membrane science. Reverse osmosis desalination plants are currently leading the the desalination market, with $\mathrm{RO}$ installations representing $60 \%$ of the total number of worldwide plants, whereas thermal processes represent just 34.8\% (Drioli et al, 2011). In Fig. 3 an example of the water desalination processes developed by the Japanese Water Re-Use Promotion Center, in co-operation with Takenaka Corporation and Organo Corporation: this process uses solar energy allowing the installation at location with no external electric energy supply (Drioli et al, 2011).

In Table 3 a list of traditional membrane technologies for water treatment is given.

The great flexibility, operational simplicity and mutual compatibility for integration of membrane operations offer the possibility of combining different membrane technologies for minimizing the limits of the single membrane units and for increasing the efficiency of the overall system.

Nowadays the most part of conventional seawater desalination plants use either RO or Multi-Stage Flash (MSF) technology. Thermal desalination is the most frequently applied technology in the Middle East, whilst membrane processes have rapidly developed and now surpass thermal processes in new plant installations due to the lesser energy consumptions (2.2.-6.7 $\mathrm{kWh} / \mathrm{m}^{3}$ for seawater $\mathrm{RO}$, with respect to $17-18 \mathrm{kWh} / \mathrm{m}^{3}$ for $\mathrm{MSF}$ ). 


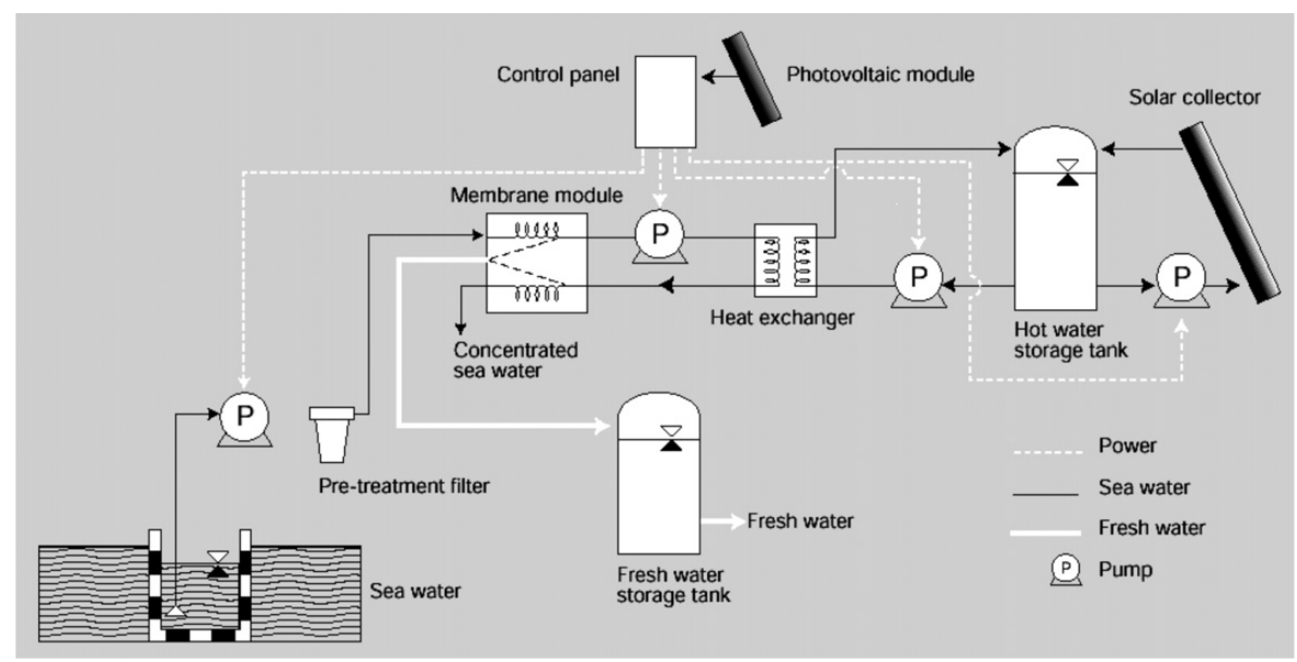

Fig. 3. Water desalination plant based on membrane process using solar energy, developed by the Japanese Water Re-use promotion center, in co-operation with Takenaka Corporation and Organo Corporation (Drioli et al, 2011).

However, high quality feedwater is required to ensure stable, long term performance, and an effective pre-treatment is essential for an efficient plant operation. In the past conventional, (i.e. conventional and physical) pre-treatment without the use of membrane technologies has been applied. Nowadays, membrane-based pre-treatments (such as MF, $\mathrm{UF}, \mathrm{NF}$ ) tend to replace conventional pre-treatment systems.

MF is a low energy-consuming technique extensively used to remove suspended solids and to lower chemical oxygen demand (COD)/biochemical oxygen demand (BOD) and silt density index (SDI). UF retains suspended solids, bacteria, macromolecules and colloids and despite of the larger pressure gradient with respect to MF, this membrane separation method is competitive against conventional pre-treatments. In an integrated membrane pretreatment (Figure 4), the benefits of lower fouling rates of RO membranes compensates the higher cost membrane pre-treatment equipment.

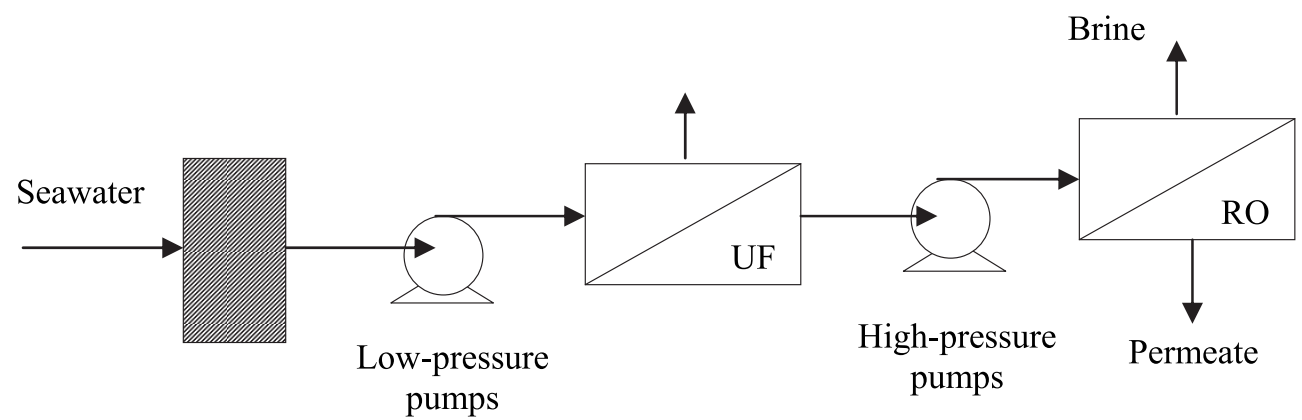

Fig. 4. Integrated (UF/RO) seawater desalination plant: UF as a pre-treatment 


\begin{tabular}{|c|c|c|c|c|}
\hline $\begin{array}{l}\text { Separation } \\
\text { process }\end{array}$ & $\begin{array}{l}\text { Membrane } \\
\text { type used }\end{array}$ & $\begin{array}{l}\text { Applied driving } \\
\text { force }\end{array}$ & $\begin{array}{c}\text { Mode of } \\
\text { separation }\end{array}$ & Applications \\
\hline $\begin{array}{l}\text { Microfiltration } \\
\text { (MF) }\end{array}$ & $\begin{array}{l}\text { symmetric } \\
\text { macroporous }\end{array}$ & $\begin{array}{l}\text { hydrostatic } \\
\text { pressure } \\
0.05-0.2 \mathrm{MPa}\end{array}$ & $\begin{array}{l}\text { size exclusion, } \\
\text { convection }\end{array}$ & $\begin{array}{l}\text { water purification, } \\
\text { sterilization }\end{array}$ \\
\hline $\begin{array}{l}\text { Ultrafiltration } \\
\qquad(\mathrm{UF})\end{array}$ & $\begin{array}{l}\text { Asymmetric } \\
\text { macroporous }\end{array}$ & $\begin{array}{l}\text { hydrostatic } \\
\text { pressure } \\
0.1-0.5 \mathrm{MPa}\end{array}$ & $\begin{array}{l}\text { size exclusion, } \\
\text { convection }\end{array}$ & $\begin{array}{l}\text { separation of } \\
\text { molecular mixtures }\end{array}$ \\
\hline $\begin{array}{l}\text { Diafiltration } \\
\text { (DF) }\end{array}$ & $\begin{array}{l}\text { asymmetric } \\
\text { macroporous }\end{array}$ & $\begin{array}{l}\text { hydrostatic } \\
\text { pressure } \\
0.1-0.5 \mathrm{MPa}\end{array}$ & $\begin{array}{l}\text { size exclusion } \\
\text { and } \\
\text { dialysation, } \\
\text { diffusion }\end{array}$ & $\begin{array}{l}\text { purification of } \\
\text { molecular mixtures, } \\
\text { artificial kidney }\end{array}$ \\
\hline $\begin{array}{l}\text { Nanofiltration } \\
\text { (NF) }\end{array}$ & $\begin{array}{l}\text { asymmetric } \\
\text { mesoporous }\end{array}$ & $\begin{array}{l}\text { hydrostatic } \\
\text { pressure } \\
0.3-3 \mathrm{MPa}\end{array}$ & $\begin{array}{l}\text { size exclusion, } \\
\text { diffusion, } \\
\text { Donnan- } \\
\text { exclusion }\end{array}$ & $\begin{array}{l}\text { separation of } \\
\text { molecular mixtures } \\
\text { and ions }\end{array}$ \\
\hline $\begin{array}{l}\text { Reverse osmosis } \\
\text { (RO) }\end{array}$ & $\begin{array}{l}\text { asymmetric } \\
\text { skin-type, } \\
\text { dense or } \\
\text { microporous }\end{array}$ & $\begin{array}{l}\text { hydrostatic } \\
\text { pressure } \\
1-10 \mathrm{MPa}\end{array}$ & $\begin{array}{l}\text { solution- } \\
\text { diffusion } \\
\text { mechanism }\end{array}$ & $\begin{array}{l}\text { sea \& brackish, water } \\
\text { desalination }\end{array}$ \\
\hline $\begin{array}{l}\text { Electrodialysis } \\
\text { (ED) }\end{array}$ & $\begin{array}{l}\text { symmetric ion- } \\
\text { exchange } \\
\text { membrane }\end{array}$ & $\begin{array}{l}\text { electrical } \\
\text { potential }\end{array}$ & $\begin{array}{l}\text { Donnan- } \\
\text { exclusion }\end{array}$ & water desalination \\
\hline $\begin{array}{c}\text { Donnan Dialysis } \\
\text { (DD) }\end{array}$ & $\begin{array}{l}\text { symmetric ion- } \\
\text { exchange } \\
\text { membrane }\end{array}$ & $\begin{array}{l}\text { concentration } \\
\text { of ions }\end{array}$ & $\begin{array}{l}\text { Donnan- } \\
\text { exclusion }\end{array}$ & water softening \\
\hline $\begin{array}{l}\text { Membrane } \\
\text { Distillation } \\
\text { (MD) }\end{array}$ & $\begin{array}{l}\text { symmetric } \\
\text { porous } \\
\text { hydrophobic } \\
\text { membrane }\end{array}$ & $\begin{array}{l}\text { Vapor } \\
\text { pressure }\end{array}$ & diffusion & $\begin{array}{l}\text { water desalination, } \\
\text { concentration of } \\
\text { solutions }\end{array}$ \\
\hline
\end{tabular}

Table 3. Membrane operations used for water treatments

Macedonio and Drioli (2010) analysed an integrated membrane-based desalination plant with membrane crystallization ( $\mathrm{MCr}$ ) as post-treatment for the recovery of salts and water contained in the NF/ RO retentate streams of a desalination plant (Fig.5).

The feed water enters into MF membrane modules to be cleaned from suspended solids and large bacteria. After MF, process water is pressurized and then sent to NF membrane modules to be cleaned from turbidity, microorganisms, hardness, multivalent ions and $10-50 \%$ of monovalent species. After NF step, the RO step requires that the process water be pressurized to overcome the osmotic pressure. In the $\mathrm{RO}$ operation the process water is separated into a permeate and a brine. $\mathrm{RO}$ brine enters into the precipitator in which is mixed with $\mathrm{Na}_{2} \mathrm{CO}_{3}$ for the removal of the $\mathrm{Ca}^{2+}$ ions of the $\mathrm{RO}$ brine as $\mathrm{CaCO}_{3}$. The process stream enters the $\mathrm{MCr}$ modules where it is separated into a permeate, a purge and a salt containing stream. 


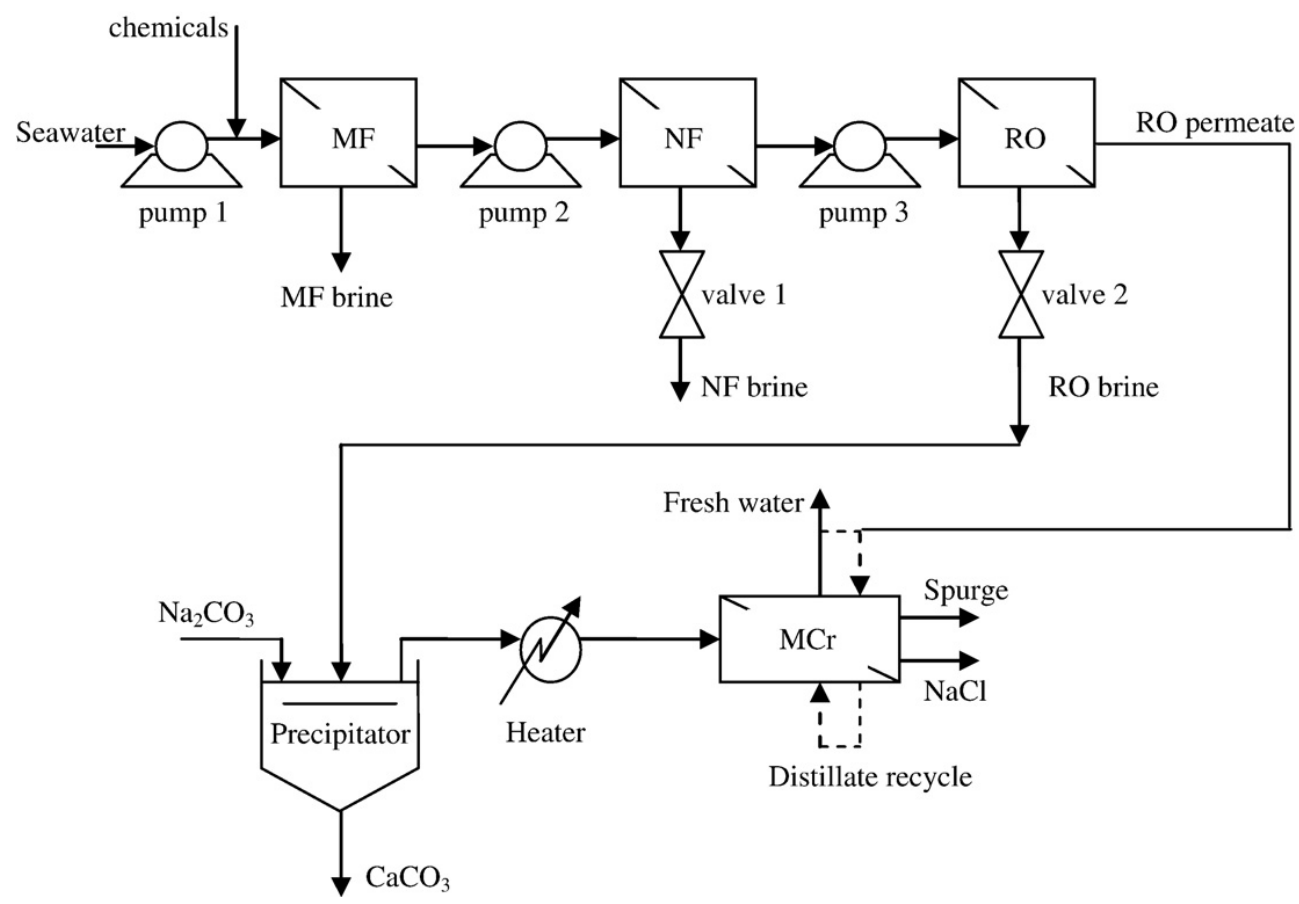

Fig. 5. Flow diagram of integrated desalination membrane-based plant (Macedonio and Drioli, 2010).

Hybrid membrane systems, in combination with conventional separation process, are advantageous in many industrial processes and in particular in desalination systems.

In recent years, the concept of simple hybrid multistage flash-reverse osmosis (MSF/RO) configuration has been applied to a number of existing or new commercial desalination plants. The SWCC Jeddah, Al-Jubail and Yanbu existing Power/Water cogeneration plants are expanded for more water production by combining with new SWRO desalination plants. The simple hybrid desalination arrangement enabled the increase of the water-topower ratio and utilized effectively the available intake/outfall facilities.

The MSF and RO operate in parallel and are entirely independent. The water product of the single pass RO unit is blended with the MSF product (Hamed, 2006)

The 100 MGD desalination plant in Fujairah (UAE) is one of the largest hybrid MSF (Multistage Flash evaporators) / RO installation in the worlds: it combines a 62.5 MGD MSF and 37.5 MGD SWRO (Fig.6).

This hybrid desalination system is designed to provide significant operational savings by reducing fuel consumption by up to 25 per cent compared with a similar-sized plant based only on MSF technology. Other key criteria influencing the design of the desalination plant were feed water quality, product water requirements and compatibility with the cogeneration of electricity. 


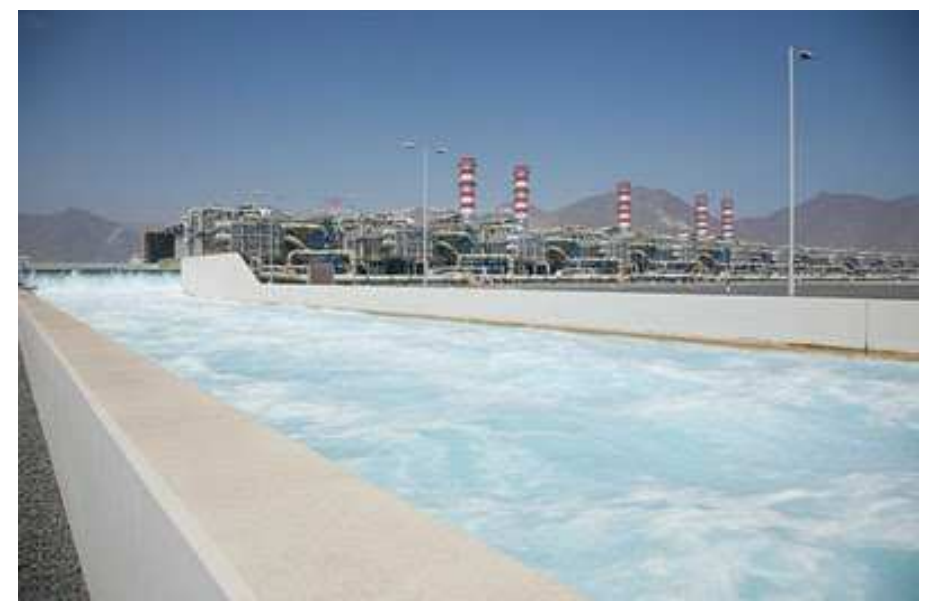

Fig. 6. Fujairah desalination plant in United Arab Emirates, from http:/ / fujairahinfocus.blogspot.com/2011/10/fujairah-power-and-desalination-plant.html

The water production system at the Fujairah desalination plant is comprised of five Doosan MSF units producing 57 million 1/day (12.5 MGD) each and one RO unit with a design capacity of 171 million 1/day (37.5 MGD). The RO unit was supplied by Ondeo Degremont. For drinking water supply, distillate from the MSF units and desalinated water from the RO plant are mixed in a distillate header and treated in a re-mineralization unit before passing into the potable water storage tanks. Prior to export to the water transmission line, potable water is stored in five potable water tanks, each with a capacity of 91 million 1 (20 million gallons).

A promising approach for pre-treatment of seawater make-up feed to MSF and SWRO desalination processes using NF membranes has been introduced by the R\&D Center (RDC) of SWCC.

NF membranes are capable to reduce significantly scale forming ions from seawater, allow high temperature operation of thermal desalination processes, and subsequently increase water productivity.

The developed fully integrated systems NF/MSF and NF/SWRO/MSF result in high water productivity and enhance thermal performance compared to the currently used simple hybrid desalination arrangements (Hamed, 2006).

\section{Wastewater treatment and reuse}

Considerable advances in MF, UF and NF technologies to recover municipal wastewater have been also achieved. Also in this case, the implementation of integrated membrane systems is growing rapidly with excellent results.

In fig. 7 the main treatment steps to recover municipal wastewater from Kuwait City and the surrounding area are reported: A conventional biological wastewater treatment plant (WWTP) treats the effluent to better than secondary effluent quality. The secondary effluent then flows to the water reclamation plant, which uses UF and RO to further treat the water for reuse. Sludge from the wastewater treatment plant is treated to allow for disposal by 


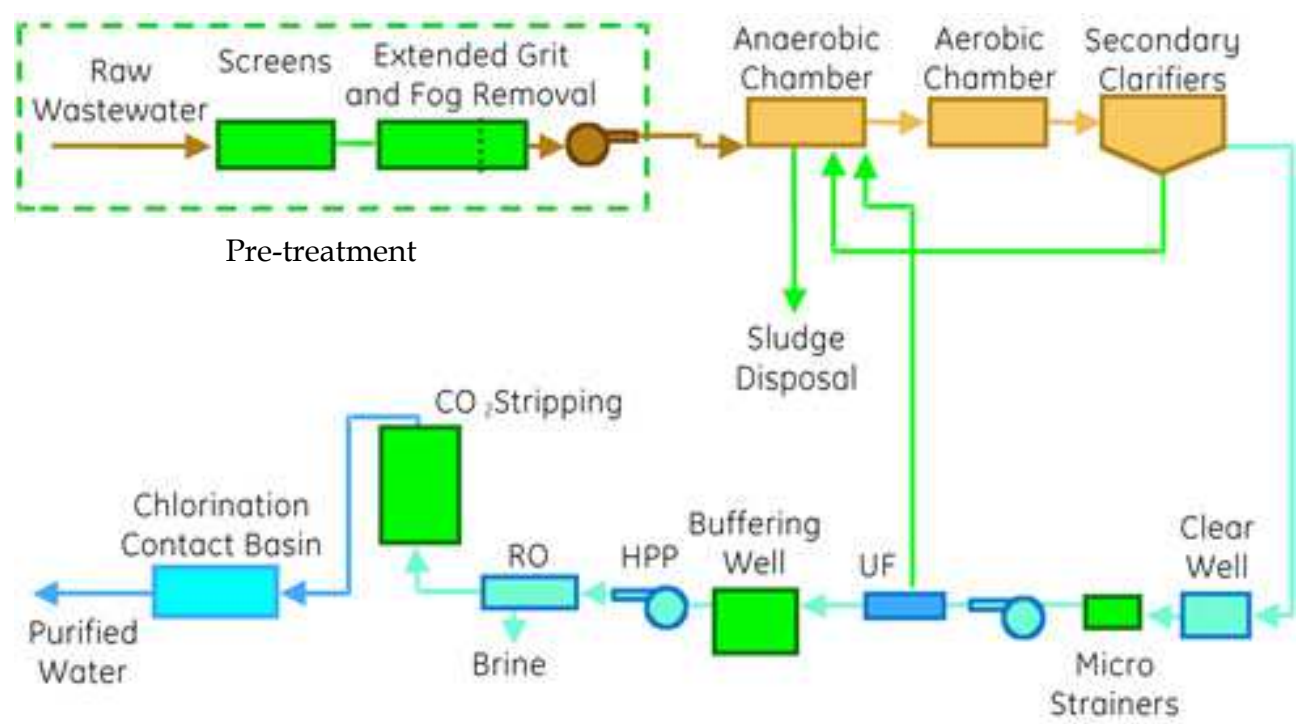

Fig. 7. Wastewater treatment facility at Sulaibiya near Kuwait City from http:/ / www.watertechnology.net/projects/sulaibiya/

landfill, incineration, or by composting. Membrane filtration was selected to provide robust pretreatment of the secondary-treated municipal effluent before being fed to the RO. Membrane filtration was chosen over conventional tertiary clarification and filtration because it reduced the plant chemical consumption and could guarantee that low turbidity water is fed to the RO. It is expected that better quality pre-treatment to the RO will lead to longer membrane life, lower operating pressure, and reduced cleaning frequency for the RO system. The UF plant utilizes Norit's X-Flow membranes, which are capillary hydrophilic hollow fibers. The UF units are operated individually. Each unit is backwashed regularly, whereby all suspended matter that is being retained by the membranes is removed from the plant. The backwash water is pumped back upstream of the WWTP to achieve the highest possible overall water recovery for the plant. The salinity of the municipal effluent has an average monthly value of $1,280 \mathrm{mg} / 1 \mathrm{TDS}$, with a maximum value of 3,014 mg/l. RO is used to desalinate the water to $100 \mathrm{mg} / \mathrm{l} \mathrm{TDS}$, as well as provide a second barrier to bacteria and viruses. RO technology is well proven for desalinating municipal effluent. The system consists of 42 identical skids in a 4:2:1 array. Approximately 21,000 membrane modules, provided by Toray of America, were required for this project. The RO product passes through a stripper to remove carbon dioxide to adjust $\mathrm{pH}$ with a minimum amount of caustic before distribution, and the product is then chlorinated before leaving the plant. RO brine is disposed of into the Persian Gulf.

Membrane bioreactors (MBR) are a combination of activated sludge treatment and membrane filtration for biomass retention. Low-pressure membrane filtration, either UF or $M F$, is used to separate effluent from activated sludge. The two main MBR configurations involve either submerged membranes (Fig. 8) or external circulation (side-stream configuration). 


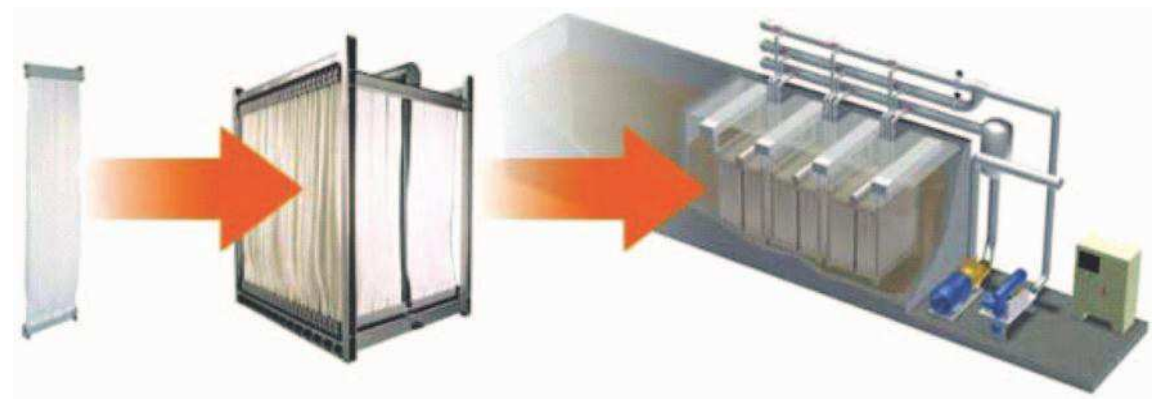

Fig. 8. Submerged membrane module for wastewater treatment. From ZeeWeed® Submerged Membrane System, from http://www.gewater.com.

Since the early MBR installations in the 1990s, the number of MBR systems has grown considerably. One key trend driving this growth is the use of MBR system for decentralized treatment and water reuse. The successful introduction of MBR systems into small scale and decentralized applications has led to the development of packaged treatment solutions from the main technology suppliers. The company Conder Products, UK, designed the package treatment plant Clereflo MBR; Zenon Environmental Inc., now a part of General Electric, produced ZeeMod ${ }^{\circledR}$.

The Pleiade ${ }^{\circledR}$ Plate \& Frame membranes produced by Orelis $\bigodot$, France, which is one of Europe's leading membrane manufacturer, are installed in skids mounted outside the bioreactor and the sludge is circulated through the module in high speed, by pumps (Fig. 9). This configuration and the Orelis membranes have several advantages over other MBR systems.

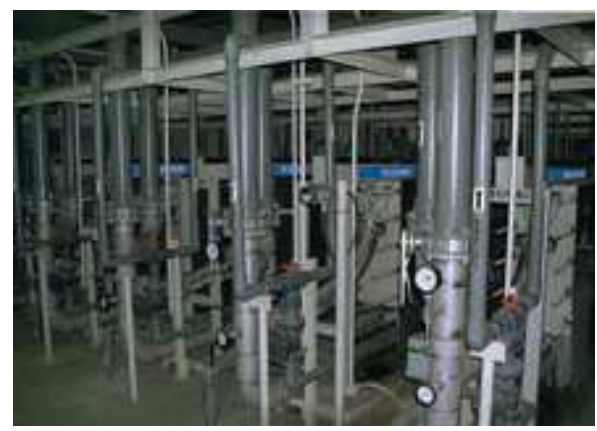

Fig. 9. Pleiade ${ }^{\circledR}$ MBR membrane bioreactor for treating $1000 \mathrm{~m}^{3} /$ day of effluent from www.vic-ws.it/site/down/PLEENG0411.pdf

The membranes are in the UF range and offer high separation capabilities $(0.02 \mu \mathrm{m}$, $\mathrm{MWCO}=40 \mathrm{kD}$ ), unlike most MBR membranes which fall under the MF range. As a result, 
the permeate quality is superb, even in very high sludge concentrations (up to $2 \%$ ) and in difficult applications. Besides TSS, the membranes effectively reject also bacteria and even viruses.

High flow rate and pressure feed of the reactor content (MLSS) into the Pleiade membrane module, enable high permeate fluxes $(60-80 \mathrm{lit} / \mathrm{m} 2 * \mathrm{hr})$. As a result, the membrane area required for treatment of a given WW flow is much lower than in most other MBR membranes.

High circulation speed over the membranes $(2 \mathrm{~m} / \mathrm{sec})$ reduces fouling accumulation, and membrane cleaning (CIP) demand.

External membrane systems enable full modularity and easy expansion of WW treatment capacity. Gao et al (2011) developed a completely green process based on the integration of MBR with UF by treating micro-polluted source water in drinking water treatment. The removal of organic matter is carried by both a biodegradation mechanism in the MBR and by the MF/UF membrane, while the nitrification in MBR removes ammonia (Fig. 10).

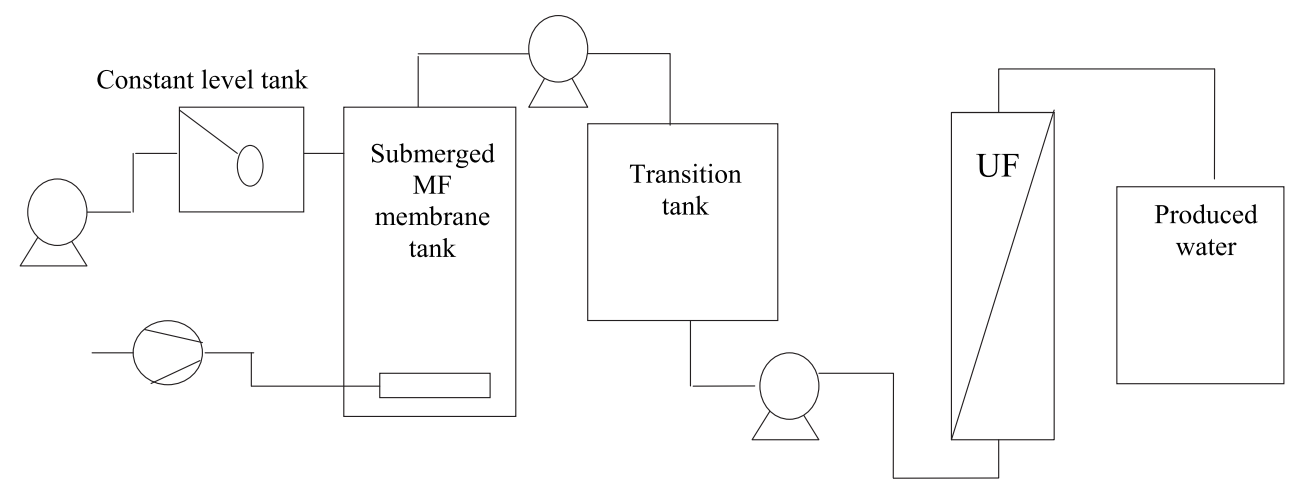

Fig. 10. Schematic diagram of the pilot scale experimental set-up MBR/UF (Gao et al, 2011)

The pulp and paper industry is one of the most water-dependent industries (Nurdan and Emre, 2010). The alkaline peroxide mechanical pulping (APMP) process has been widely applied especially in Asia (Liu et al, 2011) for the high yield, and the relatively low pollution. To achieve a closed wastewater loop, several APMP plants in the world have attempted to concentrate the total effluent by using a multi-effect evaporation system. Zhang et al (2011) studied a hybrid process UF/Multi-effect-evaporation (MEE) to concentrate effluent from APMP plants. With this new membrane concentration process, $88 \%$ of the water in the effluent can be removed, 1.4 bilion KWh power could be saved; the capital investment for MEE could also be decreased by $88 \%$ correspondingly.

The possibility of redesigning overall industrial production by the integration of various already developed membrane operations is of particular interest: low environmental impacts, low energy consumption, higher quality of final products and new available products are the advantages obtained.

The leather industry might be an interesting case study because of (i) the large environmental problems related to is operation; (ii) the low technological content of its 
traditional operations; (iii) the tendency to concentrate a large number of small-medium industries in specific districts. In Fig. 11 an ideal process based on integrated membrane operations for the tanning process is showed.

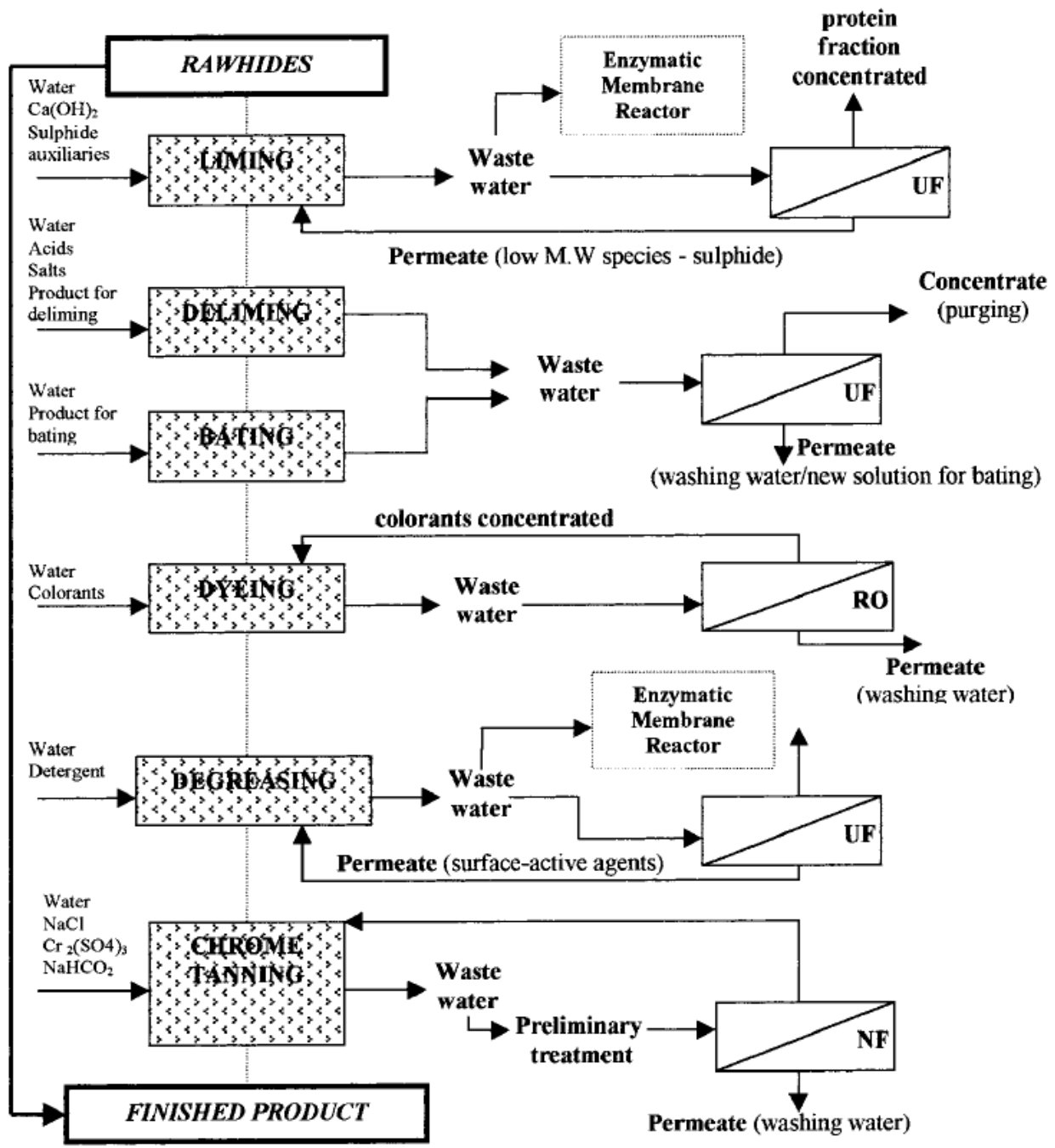

Fig. 11. Integrated membrane process proposed for the tanning process in the leather industry (Drioli \& Romano, 2001)

The pollution problems of the leather industry have been minimized one by one at the point where they originate, thereby avoiding the need for huge wastewater treatment plants at the end of the overall production line. In addition, the membrane operations act by physical mechanisms without modification of the chemical procedure at the origin of the final high quality of the leather (Cassano et al, 2003) 


\section{Gas separation}

In Table 4 the membrane sales involved for industrial gas separations are shown.

\begin{tabular}{|c|c|c|}
\hline \multirow{2}{*}{ Application } & \multicolumn{2}{|c|}{ Annual membrane system sales (106 U.S. \$) } \\
\hline & Year 2010 & Year 2020 \\
\hline Nitrogen from air & 100 & 125 \\
\hline Oxygen from air & 10 & 30 \\
\hline $\begin{array}{l}\text { Hydrogen } \\
\mathrm{H}_{2} / \text { gas }\left(\mathrm{CO}, \mathrm{N}_{2}, \mathrm{C}_{1}, \mathrm{C}_{2}\right) \\
\mathrm{H}_{2} / \operatorname{gas}\left(\mathrm{C}_{3+}, \mathrm{CO}_{2}\right) \\
\end{array}$ & $\begin{array}{l}40 \\
20\end{array}$ & $\begin{array}{l}80 \\
70\end{array}$ \\
\hline $\begin{array}{l}\text { Natural gas } \\
\mathrm{CO}_{2} \text { removal } \\
\mathrm{NGL} \mathrm{removal} \mathrm{and} \mathrm{recovery}_{\mathrm{N}_{2} \text { removal, dehydration }}\end{array}$ & $\begin{array}{l}60 \\
20 \\
10\end{array}$ & $\begin{array}{l}100 \\
50 \\
25\end{array}$ \\
\hline Vapour $\left(\mathrm{C}_{2+}\right) /$ Gas $\left(\mathrm{N}_{2}, \mathrm{Ar}\right)$ & 30 & 90 \\
\hline Vapour/Vapour (including dehydration) & 20 & 100 \\
\hline Air dehydration/other & 30 & 60 \\
\hline TOTAL & 340 & 730 \\
\hline Annual growth, \% & 8 & 8 \\
\hline
\end{tabular}

Table 4. Sales estimates and sales predicted for the principal gas and vapour separation applications

Nowadays, obtaining cheap high purity gases or enriched gas mixtures (the air, in particular) is a very important problem in industry and medicine as well as in everyday life (Bodzek, 2000).

Methods for air separation or oxygen enrichment can be divided into two groups (Freeman et al, 2006): cryogenic and non - cryogenic. The gaseous oxygen and nitrogen market is dominated by cryogenic distillation of air, and vacuum swing adsorption (Koros et al, 2000). Of the non - cryogenic methods, selective adsorption on zeolites and carbon adsorbents are available (Lin \& Guthrie, 2006), and more and more attention is attracted to the membrane separation techniques (Dhingra \& Marand, 1998). The success of polymeric membranes has been largely based on their mechanical and thermal stability, along with good gas separation properties. The process of membrane separation is continuous, has a low capital cost, low power consumption, and the membranes, at least in gas separation, do not require regeneration (Vansant \& Dewolfs, 1990).

Nitrogen production today is the largest GS process in use. Nitrogen gas is used in many applications (e.g., to prevent fires and explosions in tanks and piping systems and to prevent equipment degradation, during shutdown periods, in compressors, pipelines and reactors). Single-stage membrane operation is preferred. Air is pressurized and fed into the membrane separators; faster gases $\left(\mathrm{O}_{2}, \mathrm{CO}_{2}\right.$, water vapor) permeate through the polymeric fiber walls, are collected and vented to the atmosphere while the slower, non-permeate $\mathrm{N}_{2}$ gas is available at the other end of the separator. 
Oxygen production by membrane systems is still underdeveloped, since most of the industrial $\mathrm{O}_{2}$ applications require purity higher than $90 \%$, which is easily achieved by adsorption or cryogenic technologies but not by single-stage membranes.

New materials are being developed that could possibly have higher permeabilities than conventional solid electrolytes. Promising oxygen permeation have been obtained in many perovskite systems (Zhu et al, 2009; Stiegel, 1999). The dense perovskite type membranes transport oxygen as lattice ions at elevated temperatures with infinite selectivity ratios in $\mathrm{O}_{2}$ separations.

The oxygen-ion conducting membranes must operate above $700^{\circ} \mathrm{C}$ : an efficient and costeffective way to recover the energy contained in the non- permeate, oxygen-depleted stream is that of integrating the membrane system with a gas turbine (Fig. 12) (Drioli \& Romano, 2001).

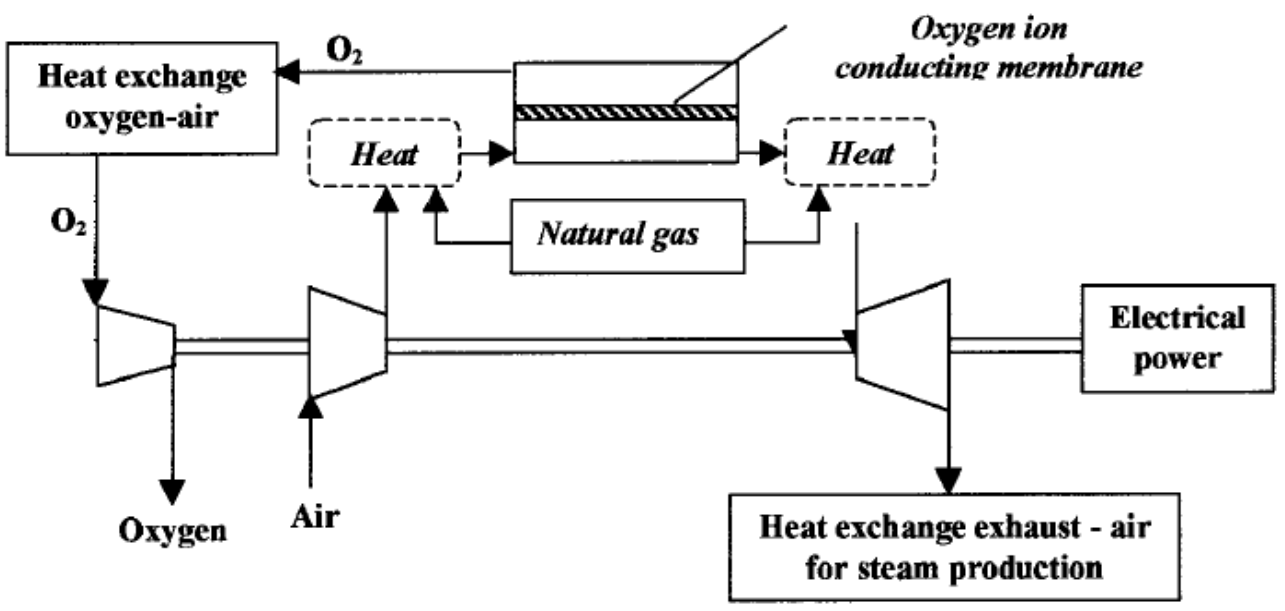

Fig. 12. Integrated system for $\mathrm{O}_{2}$ and power productions ( Drioli \& Romano, 2001).

Hydrogen recovery was among the first large-scale commercial applications of membrane GS technology. The commercial success in the mid-1970's in Louisiana of the Permea hollow-fiber Prism system for in-process recycling of hydrogen from ammonia purge gases (Fig. 13) was the starting point of the penetration of membrane technology in large-scale manufacturing. A two-step membrane design was chosen for this ideal application for membrane technology: the ammonia reactor operates at high pressures (ca. 130 bar), thus providing the necessary driving force for separation; the $\mathrm{H}_{2} / \mathrm{N}_{2}$ membrane selectivity is high and the feed gas is free of contaminants.

This technology has been extended to other situations. In Table 5, some recent $\mathrm{H}_{2}$ membrane applications are listed. $\mathrm{H}_{2}$ recovery from refinery streams is an emerging field for membrane GS in the petrochemical industry; it is a key approach to meet the increased demand of hydrogen (for hydrotreating, hydrocracking or hydrodesulfurization processes) owing to new environmental regulations. An example is the $\mathrm{H}_{2}$ recovery from high pressure purge gas of a hydrotreater. 


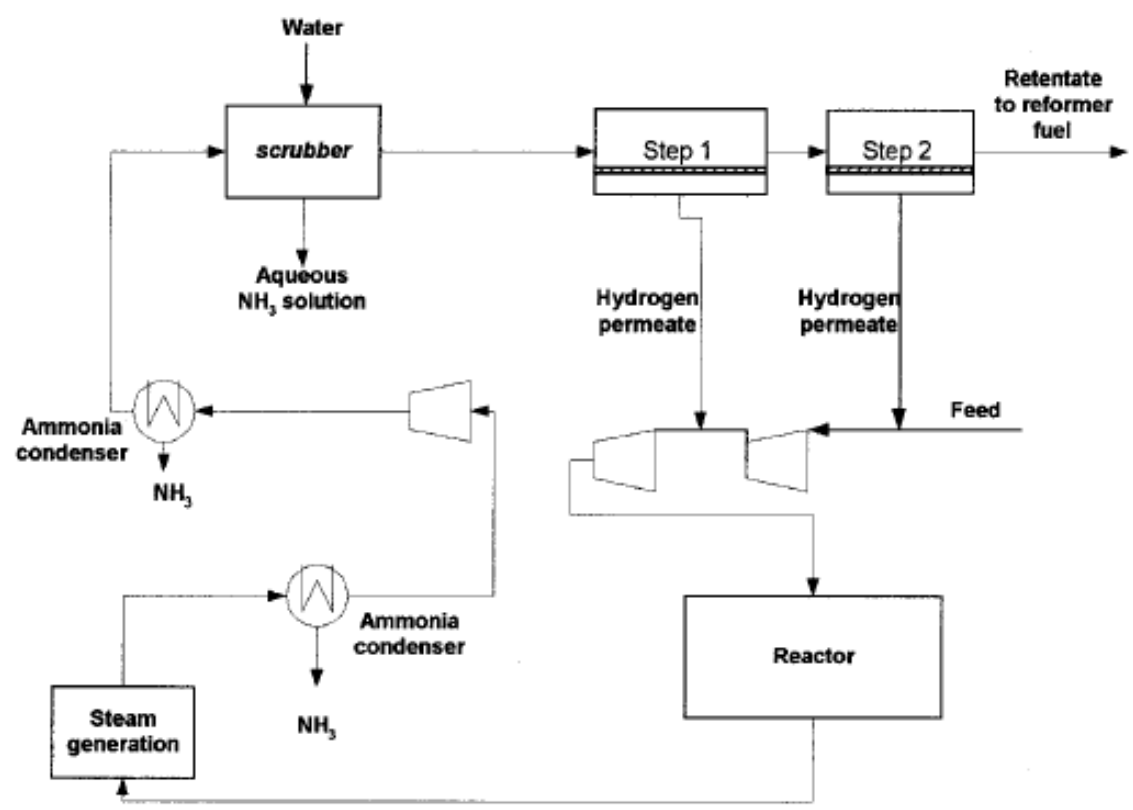

Fig. 13. Plant for $\mathrm{H}_{2}$ recovery from ammonia synthesis (Drioli \& Romano, 2001)

\begin{tabular}{ll}
\hline Refining & Chemical/Petrochemical \\
\hline Catalytic reformer off gases & $\begin{array}{l}\text { Synthesis gas composition adjustment } \\
\text { (IGCC) } \\
\text { HDT/Recycle purge gases }\end{array}$ \\
Refinery fuel gases & Ammonia purge gases \\
PSA off gases & Polypropylene purge \\
& Polyethylene purge \\
& Styrene off gases \\
Coke oven gases \\
Electrolysis gases \\
Cyclohexane plant gases
\end{tabular}

Table 5. $\mathrm{H}_{2}$ membrane applications

In a comparison of three separation technologies (membrane, PSA, cryogenic distillation) applied for $\mathrm{H}_{2}$ recovery from refinery off-gas, Spillman (1989) reported that the use of membranes represent the best choice. An evaluation of these processes is provided in terms of sustainability indexes. The Energy Intensity of the membrane system is the lowest; the Mass Intensity is less than $50 \%$ of that for the conventional separations; the membrane system occupies a tenfold lower area required by PSA and cryogenic distillation of corresponding capacity (highest Productivity/Footprint ratio). 
Carbon dioxide removal from natural gas (natural gas sweetening) is mandatory to meet pipeline specifications (e.g., down to $2 \%$ vol. in U.S.A.), since $\mathrm{CO}_{2}$ reduces the heating value of natural gas, is corrosive and freezes at a relatively high temperature, forming blocks of dry ice that can clog equipment lines and damage pumps. Membrane technology is attractive for $\mathrm{CO}_{2}$ and $\mathrm{H}_{2} \mathrm{~S}$ removal, because many membrane materials are very permeable to these species (enabling a high recovery of the acid gases without significant loss of pressure in the methane pipeline product gases), and because treatment can be accomplished using the high wellhead gas pressure as the driving force for the separation. A high natural gas recovery ( $>95 \%$ ) can be achieved in multi-stage systems.

Cynara-NATCO produces hollow fiber modules for $\mathrm{CO}_{2}$ removal and has provided a membrane system (16 in. modules) for the natural gas sweetening in an offshore platform in the Thailand gulf $\left(830,000 \mathrm{Nm}^{3} / \mathrm{h}\right)$, which is the biggest membrane system for $\mathrm{CO}_{2}$ removal. The Natco Group has been awarded in 2008 a \$24.9 million contract to provide membrane separation technology and equipment to capture $\mathrm{CO}_{2}$ for re-injection in Bouri. Eni Oil Limited Libyan Branch operates the Bouri production platforms in the Mediterranean Sea, one of which will house the pre-treatment equipment and membrane systems intended to treat more than 160MM SCFD gas.

The Cynara(R) membrane system has been designed for the selective capture of $\mathrm{CO}_{2}$ from the gas stream for this retrofit project on the existing platform. Natco will design, engineer, and fabricate four membrane skids and related valving, as well as pretreatment equipment. The contract was awarded in May 2008.

The integration of membranes with other well-established separation processes in the chemical and petrochemical industries, , was considered in different works (Doshi, 1987; Choe et al, 1987; Dosh \& Dolan, 1995; Bhide et al, 1998). Usually, the combination membranes / PSA is considered in $\mathrm{H}_{2}$ separation, while hybrid membranes + amine absorption are applied to the $\mathrm{CO}_{2}$ separation.

A comparison of the separation cost for the membrane process with diethanolamine (DEA) absorption showed that the membrane process is more economical for $\mathrm{CO}_{2}$ concentrations in the feed in the range 5-40 mol\% (Bhide et al, 1998).

If membrane processes are not economically competitive because of the high $\mathrm{H}_{2} \mathrm{~S}$ concentration in the feed, the separation cost could be significantly lowered by using hybrid membrane processes. In the block diagram of Fig.14 the membrane unit removes two-thirds of the $\mathrm{CO}_{2}$ and the amine plant removes the remaining. The combined plant is significantly less expensive than an all-amine or all-membrane plant.

A hybrid system (Cynara membranes + amine absorption) is operating since 1994 in Mallet (Texas, U.S.A.) to perform the bulk removal of $\mathrm{CO}_{2}$ from associated gas $\left(90 \% \mathrm{CO}_{2}\right.$ and heavy hydrocarbons), before downstream treating. The membrane system offered a $30 \%$ reduction in operating cost when compared with a methyl diethanolamine (MDEA) system and significantly reduced the size of the subsequent operations (Blizzard et al, 2005).

An integrated system combining membrane permeation and pressure swing adsorption (PSA) has been developed for $\mathrm{CO}_{2} / \mathrm{N}_{2}$ gas separation (Esteves and Mota, 2007). By using the membrane as a pre-bulk separation unit and coupling it to the PSA, the separation performance of the hybrid scheme is enhanced with respect to that of the two stand-alone 


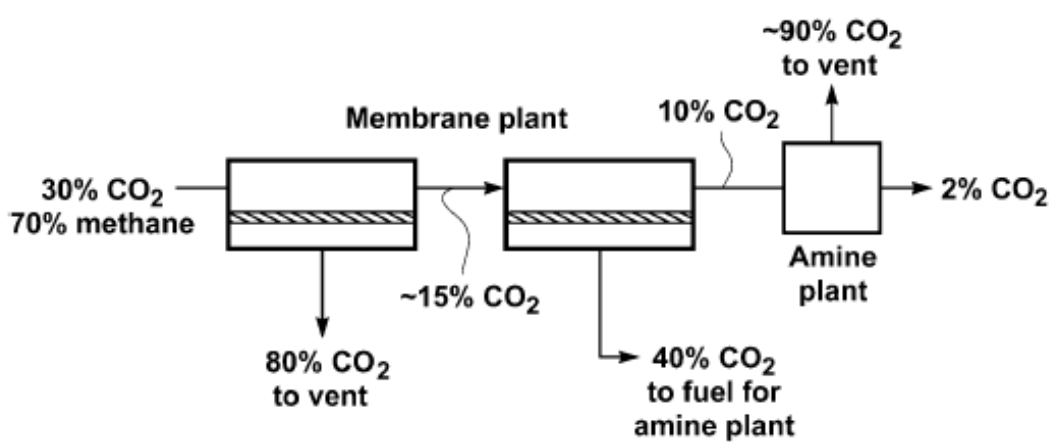

Fig. 14. Membrane/amine hybrid plant for the treatment of natural gas (Baker \& Lokhandwala, 2008).

units. Instead of constant-composition regular feed, the PSA is fed with a mixture which is progressively enriched in the more adsorbed component during the pressurization and high-pressure adsorption steps of the cycle. This results in sharper concentration fronts. The hybrid has been applied successfully to the bulk separation of an $30: 70 \mathrm{~mol} \% \mathrm{CO}_{2} / \mathrm{N}_{2}$ mixture over activated carbon. Process performance is reported in terms of product recovery and purity at cyclic steady state. Numerical simulations were validated by experimental work on a composite membrane and a laboratory-scale PSA unit.

MTR (Membrane Technology and Research, Inc.) has proposed an innovative retro-fit process for the post-combustion carbon capture and sequestration (CCS) of existing coalfired power plants (Merkel et al., 2010). According to preliminary calculations, a two stage membrane process (Figure 15) should be able to recover $90 \%$ of the $\mathrm{CO}_{2}$ released by the power plant at a competitive cost of $23 \$ /$ ton $\mathrm{CO}_{2}$ sequestrated. The selected lower cost configuration uses a blower upstream of the first membrane unit and a vacuum pump downstream in order to boost the driving force for the separation. At the same time, in the second membrane module the air to be fed to the boiler strips part of the $\mathrm{CO}_{2}$ in the $\mathrm{N}_{2}$ enriched flue gas from the first membrane module, thereby recycling $\mathrm{CO}_{2}$ and building a higher $\mathrm{CO}_{2}$ concentration for the first membrane module: as a consequence, the sequestered $\mathrm{CO}_{2}$ flux in the first membrane unit is enhanced.

MTR is now involved in a contract with the US Department of Energy for the construction of a membrane skid containing MTR's Polaris membranes capable of $90 \% \mathrm{CO}_{2}$ capture from a 20 tons-of- $\mathrm{CO}_{2} /$ day slipstream of coal fired flue gas. The skid will be operated during a 6 month field test at Arizona Public Service's Cholla power plant. (http://www.mtrinc.com/news.html\#DOE14mil).

In the process industry the final choice of a separation process is the result of a balance between the economics, the desired purity and recovery of the product and other conditions and restrictions, such as the desired capacity and the composition of the feed and the possibility of integration with other processes. In this logic, the integration of commercial membrane separation units in the recovery of ethylene or propylene monomer from polyolefin resin degassing vent streams has been proposed by Baker et al (1998). A simplified flow scheme of the process that generates such streams is shown in Fig. 16(a). 
(5)

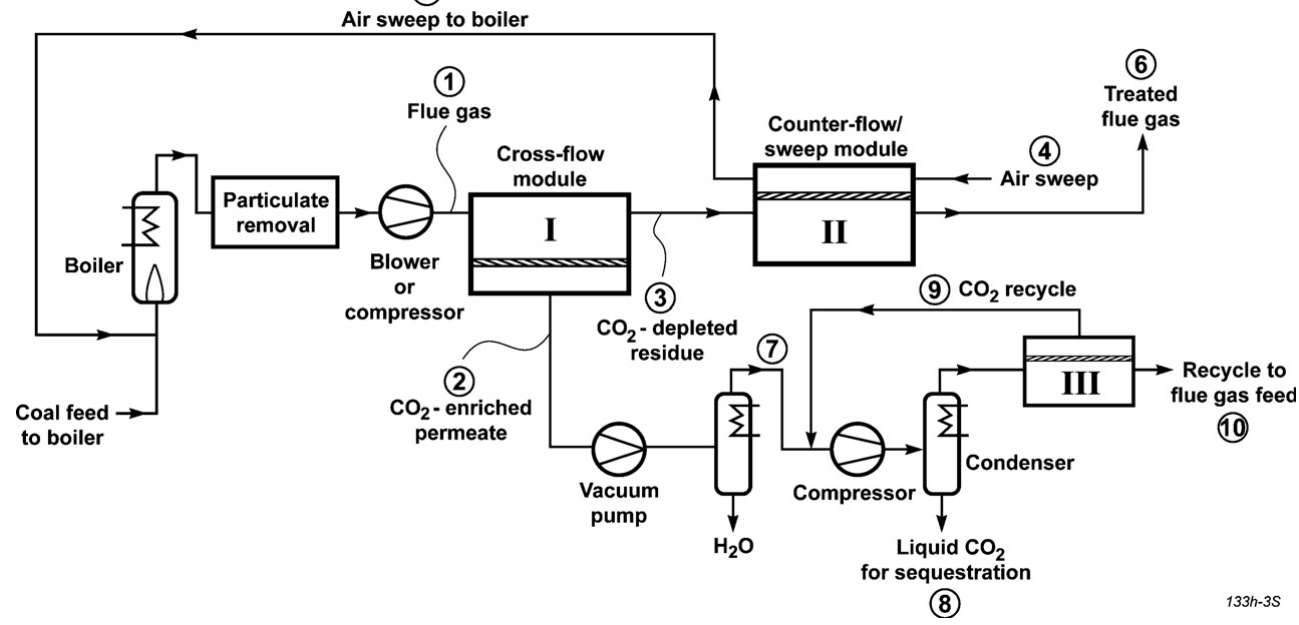

Fig. 15. Simplified flow diagram of a two-step counter-flow/sweep membrane process to capture and sequester $\mathrm{CO}_{2}$ in flue gas from a coal-fired power plant. The base-case membrane with a $\mathrm{CO}_{2}$ permeance of $1000 \mathrm{gpu}$ and a $\mathrm{CO}_{2} / \mathrm{N}_{2}$ selectivity of 50 was used in the calculations (Merkel et al, 2010).

(a) Conventional Plant

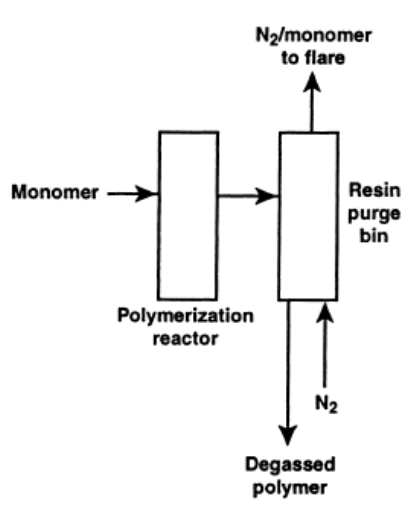

(b) The Membrane Solution

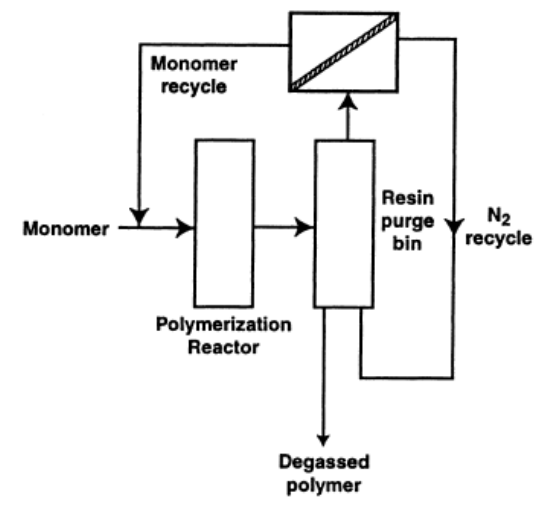

Fig. 16. A schematic diagram of monomer recovery and nitrogen recycle from polyolefin plant resin degassing operations: (a) conventional plant (b) membrane vapor gas separation system (Baker et al, 1998)

In a typical polyolefin polymerization plant, after polymerization, the polymer is removed to a low-pressure chamber. amounts of sorbed monomers and processing solvents, which must be removed before the polymer can be used. Therefore, the raw polymer is passed to large resin degassing bins through which nitrogen is circulated.

In the past, no economical method of separating these gases was available, so the stream was used as low grade fuel and the monomer content lost. The value of these potentially 
recoverable monomers in a typical polymerization plant is very high. The placement of a membrane to recover and recycle the gases is shown schematically in Fig. 16(b).

Membrane vapor gas separation systems have been installed worldwide. The main membrane applications in the petroleum industry are vapor recovery in tank farms and hydrogen recovery in refineries and chemical plants. Other developed applications of the membrane technology in refineries include solvent recovery in lube oil manufacturing (Max-DeWax developed jointly by Grace Division and Exxon Mobil) and aromatics removal from gasoline.

\section{Conclusion}

The development of innovative processes that follow the process intensification strategy for a sustainable industrial growth is critical to the production by non-polluting, defect-free and safe industrial processes. Membrane operations show a higher efficiency than conventional separation and reaction unit operations. They offer new options for the razionalization of innovative production cycles. Membrane engineering plays a crucial role in water desalination, in municipal water reuse (by MBR), in petrochemicals and in the field of gaseous separations. There are also some interesting opportunities to integrate membrane operations into existing industrial processes to achieve the benefits of process intensification.

\section{References}

Baker, R.W., Wijmans, J.G. and Kaschemekat, J.H. (1998). The design of membrane Vapor gas separation systems. J. Membr. Sci. Vol. 151 pp.55-62 ISSN 0376-7388

Baker, R. \& Lokhandwala, K. (2008). Natural Gas Processing with Membranes: An Overview. Ind. Eng. Chem. Res. Vol. 47 No 7 pp.2109-2121 ISSN 0888-5885.

Bhide, B.D.; Voskericyan, A.; Stem, S.A. (1998) Hybrid processes for the removal of acid gases from natural gas. J. Membr. Sci. Vol. 140 No 1 pp.27-49 ISSN 0376-7388

Blizzard, G.; Parro, G.; Hornback, K. (2005). Mallet gas processing facilities uses membranes to efficiently separate $\mathrm{CO}_{2}$. Oil \& Gas Journal Vol. 103 No 14 pp 48-53.

Bodzek, M. (2000) Membrane techniques in air cleaning. Pol. J. Environm. Stud. Vol. 9. No.1, pp. 1-12 ISSN 1230-1485.

Cassano, A; Adzet, J; Molinari, R.; Buonomenna, M.G.; Roig, J; and Drioli, E. (2003) Membrane treatment by nanofiltration of exhausted vegetable tannin liquors from the leather industry. Water Research. Vol. 37, pp. 2426-2434 ISSN 0043-1354.

Charpentier, J.C. (2007). In the frame of globalization and sustainability, process intensification, a path to the future of chemical and process engineering (molecules into money). Chemical Engineering and Processing: Process Intensification, Vol. 134, No. 1-3, pp.84 92, ISSN 0255-2701

Choe, J.S.; Auvil, S.R.; Agrawal, R. (1987) Process for separating components of a gas stream" US Patent 4,701,187

Cobb, C.; Schuster, D.; Beloff, B.; Tanzil, D. (2007). Benchmarking Sustainability.Chemical Engineering Progress, Vol. 104, No.6, pp. 38-42, ISSN 0360-7275

Dhingra , S.S. \& Marand, E. (1998) Mixed gas transport study through polymeric membranes , J. Membr.Sci. Vol. 141 No 1 pp 45-63 ISSN 0376-7388 
Doshi, K.J. (1987) Enhanced gas separation process, US Patent 4,690,695, Union Carbide.

Doshi, K.J.; Dolan, W.B. (1995) Process for the rejection of $\mathrm{CO}_{2}$ from natural gas", US Patent $5,411,72, \mathrm{UOP}$.

Drioli, E; Romano, M. (2001). Progress and New Perspectives on Integrated Membrane Operations for Sustainable Industrial Growth. Ind. Eng. Chem. Res. Vol. 40, pp. 1277-1300, ISSN 0888-5885

Drioli, E; Stankiewicz, A; Macedonio, F. (2011). Membrane Engineering in process intensification-An overview. J. Membr. Sci. Vol. 380, pp. 1-8, ISSN 0376-7388

Esteves, I.A.A.C., Mota, J.P.B. (2007). Hybrid Membrane/PSA Processes for $\mathrm{CO}_{2} / \mathrm{N}_{2}$ Separation. Adsorption Science \& Technology Vol. 25, pp. 693-715 ISSN 0263-6174.

Freeman , B; Yampolskii , Y; Pinnau , I. (2006) Eds., Materials Science of Membranes for Gas and Vapor Separation, John Wiley and Sons, Ltd. , Chichester ISBN 9780470029039.

Gao, W; Liang, H; Wang, L.; Chang, H.-q, , Li, G-b. (2011) Pilot Study of Integrated MF based MBR and UF for Drinking Water Production by Treating Micropolluted Source Water. IPCBEE Vol. 14, pp. 11-16, ISSN 2010-4618

Hamed, O.A. (2006) Overview Of Hybrid Desalination Systems - Current Status And Future Prospects. Desalination Vol. 186, pp. 207-214, ISSN 0011-9164

Koros , W.J.; Mahajan, R.(2000) Pushing the limits on possibilities for large scale gas separation: which strategies? J. Membr. Sci. Vol. 175 No. 1 pp. 181-196 ISSN 03767388

Lin, L. \& Guthrie, J.T. (2006) Novel oxygen - enhanced membrane assemblies for biosensors. J. Membr. Sci. Vol. 278 No 1-2 pp 173-180. ISSN 0376-7388

Macedonio, F.; Drioli, E. (2010). An exergetic analysis of a membrane desalination system. Desalination Vol. 261, pp. 293-299, ISSN 0011-9164

Merkel, T.C.; Lin, H.; Wei, X.; Baker, R. (2010). Power plant post-combustion carbon dioxide capture: an opportunity for membranes, J. Membr. Sci. Vol. 359 No 1-2 pp 126-139. ISSN 0376-7388

Nurdan, B.; Emre, K. (2010) Economic evaluation of alternative wastewater treatment plant options for pulp and paper industry. Sci. Total. Environ. Vol. 408, No.24, pp.60706078, ISSN 0048-9697.

Spillman, R. (1989) Economics of gas separation by membranes. Chem.Eng. Prog. Vol. 85, pp.41-62, ISSN 0360-7275.

Stiegel, G. J. (1999) Mixed conducting ceramic membranes for gas separation and reaction. Membr. Technol. Vol. 1999 No 110 pp 5-7 ISSN 0958-2118

United Nations General Assembly (1987). Report of the World Commission on Environment and Development: Our Common Future

Vansant, E.F. \& Dewolfs, R. (1990) Gas Separation Technology , Elsevier , 1990 ISBN 0444882308

Zhang, Y; Cao, C-Y; Feng, W-Y; Xue, G-X; Xu, M. (2011) Performance of a pilot scale membrane process for the concentration of effluent from alkaline peroxide mechanical pulping plants. BioResources. Vol.6, No.3, pp. 3044-3054, ISSN 19302126.

Zhu, X; Sun, S; Cong, Y; Yang, W. (2009) Operation of perovskite membrane under vacuum and elevated pressures for high-purity oxygen production. J. Membr. Sci. Vol.345 pp 47-52 ISSN 0376-7388. 


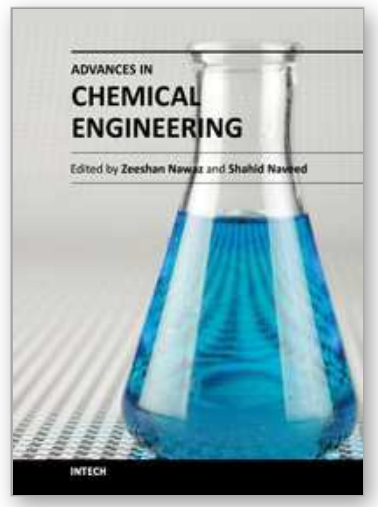

\author{
Advances in Chemical Engineering \\ Edited by Dr Zeeshan Nawaz
}

ISBN 978-953-51-0392-9

Hard cover, 584 pages

Publisher InTech

Published online 23, March, 2012

Published in print edition March, 2012

Chemical engineering applications have been a source of challenging optimization problems in terms of economics and technology. The goal of this book is to enable the reader to get instant information on fundamentals and advancements in chemical engineering. This book addresses ongoing evolutions of chemical engineering and provides overview to the sate of the art advancements. Molecular perspective is increasingly important in the refinement of kinetic and thermodynamic molding. As a result, much of the material was revised on industrial problems and their sophisticated solutions from known scientists around the world. These issues were divided in to two sections, fundamental advances and catalysis and reaction engineering. A distinct feature of this text continues to be the emphasis on molecular chemistry, reaction engineering and modeling to achieve rational and robust industrial design. Our perspective is that this background must be made available to undergraduate, graduate and professionals in an integrated manner.

\title{
How to reference
}

In order to correctly reference this scholarly work, feel free to copy and paste the following:

Maria Giovanna Buonomenna, Giovanni Golemme and Enrico Perrotta (2012). Membrane Operations for Industrial Applications, Advances in Chemical Engineering, Dr Zeeshan Nawaz (Ed.), ISBN: 978-953-51-03929, InTech, Available from: http://www.intechopen.com/books/advances-in-chemical-engineering/membraneoperations-for-industrial-applications

\section{INTECH}

open science | open minds

\section{InTech Europe}

University Campus STeP Ri

Slavka Krautzeka 83/A

51000 Rijeka, Croatia

Phone: +385 (51) 770447

Fax: +385 (51) 686166

www.intechopen.com

\section{InTech China}

Unit 405, Office Block, Hotel Equatorial Shanghai

No.65, Yan An Road (West), Shanghai, 200040, China

中国上海市延安西路65号上海国际贵都大饭店办公楼 405 单元

Phone: +86-21-62489820

Fax: $+86-21-62489821$ 
(C) 2012 The Author(s). Licensee IntechOpen. This is an open access article distributed under the terms of the Creative Commons Attribution 3.0 License, which permits unrestricted use, distribution, and reproduction in any medium, provided the original work is properly cited. 